\title{
HIV prevention by vaccine
}

\author{
Robert Gallo \\ From 17th International Symposium on HIV and Emerging Infectious Diseases (ISHEID) \\ Marseille, France. 23-25 May 2012
}

Three major HIV vaccine efficacy clinical trials have now been completed. Two failed, one of the two even increased infection and the third was modestly successful. First: VaxGen, used conventional gp120 protein and like in monkey trials it failed likely due to type specific Abs and perhaps inadequate $\mathrm{Ab}$ titans; the second, by the Vaccine Research Center (VRC) and Merck based solely on CMI and predictably failed. Less predictably it actually increased the numbers infected. This was likely due to use as a vector of an adenovirus strain already exposed to a sizeable percentage of people from earlier infections, thereby leading to increased T-cell activation which is accompanied by an increase in CCR5 co-receptor for HIV and consequently to increased susceptibility to HIV infection. The third large efficacy trial involved a novel gp120 delivered by the canary pox virus known as ALVAC made by Sanofi as well as some other HIV genes and boosted by a gp120 containing a herpes virus small sequence known as Gd. This trial was run by Colonel Dr. Nelson Michael and his co-workers in the U.S. Army AIDS research group in collaboration with colleagues in Thailand and resulted in modest success associated with Abs (not CMI) which binds V2 of gp120 and without detectable neutralizing $\mathrm{Ab}$ activity. Of great interest to us was the short duration of the Abs resulting in far greater success in the first half year than in the remaining part of the study. This is typical for Abs to gp120, and it is precisely what we have found in our primate challenge experiments with our candidate vaccine, a complex of gp120 with binding region of CD4 which we (A. DeVico, G. Lewis, T. Fouts, and Y. Guan) call the full length single chain (FLSC).

I will summarize our rationale for the FLSC, our updated primate results, and our plans for clinical trials in collaboration with Sanofi, N. Michael and his group, and the Gates Foundation.

Published: 25 May 2012

Institute of Human Virology, Baltimore, USA
doi:10.1186/1742-4690-9-S1-15

Cite this article as: Gallo: HIV prevention by vaccine. Retrovirology 20129 (Suppl 1):15.
Submit your next manuscript to BioMed Central and take full advantage of:

- Convenient online submission

- Thorough peer review

- No space constraints or color figure charges

- Immediate publication on acceptance

- Inclusion in PubMed, CAS, Scopus and Google Scholar

- Research which is freely available for redistribution
() Bïomed Central
C Biomed Central

(c) 2012 Gallo; licensee BioMed Central Ltd. This is an Open Access article distributed under the terms of the Creative Commons Attribution License (http://creativecommons.org/licenses/by/2.0), which permits unrestricted use, distribution, and reproduction in any medium, provided the original work is properly cited. 